\title{
CZY MOŻNA MÓWIĆ O ISTOCIE I NATURZE KOBIETY?
}

Czy można mówić o istocie i naturze kobiety? Wielu to robi, także Edyta Stein, która posługuje się przede wszystkim pojęciem natury, jak również przeznaczenia i powołania, jako określanymi przez naturę. Słowo „istota” pojawia się rzadko w tym kontekście. Cel rozważań Edyty Stein, zawartych w zbiorze Die Frau ${ }^{1}$, jest praktyczny. Chodzi o sprawy wychowania i kształcenia kobiet, a także bliski temu problem ich pracy zawodowej.

Wychowanie i kształcenie musi się liczyć z naturą wychowanków i wychowanek, z tym, jakie są wpisane w tę naturę mozliwości i konieczności. Obecność jakoś określonej, niezmiennej istoty jest tu założeniem przyjmowanym jako oczywiste. Jednostka staje się sobą, rozwija się i działa zgodnie $\mathrm{z}$ naturą. Zewnętrzne uwarunkowania i oddziaływania mogą sprzyjać rozwojowi człowieka lub przeszkadzać w nim, ostatecznie jednak nie da się niczego zbudować wbrew naturze (dokładniej - naturę przezwyciężyć może tylko łaska). Człowiek żyje, dorasta i działa zawsze w pewnej sytuacji historycznej i społecznej, staje wobec pewnych oczekiwań, ograniczeń, przymusów. Pojawia się więc pytanie o zgodność (lub niezgodność) tych zewnętrznych uwarunkowań z naturą, rozumianą jako coś, co zakreśla pewne granice możliwości, poza którymi zaczyna się to, co z naturą niezgodne, co jej się przeciwstawia. Wiążą się z tym pytania o życiowe i zawodowe powołanie kobiety.

${ }^{1}$ E. Stein, Die Frau. Ihre Aufgabe nach Natur und Gnade, Edith Steins Werke, Bd. 5, Editions Nauwelaerts, Freiburg 1959. 
Edyta Stein patrzy na sprawę natury kobiety z różnych stron - przede wszystkim jako filozofka, osadzona $w$ tradycji fenomenologii oraz filozofii klasycznej, arystotelesowskiej i scholastycznej, ale także z perspektywy doświadczenia pedagogicznego i dydaktycznego oraz postawy wiary religijnej, z horyzontu nadprzyrodzonego powołania człowieka i łaski, wreszcie patrzy jako ona sama, konkretna osoba, mądra, samodzielna, silna, dojrzała kobieta. Wszystkie te perspektywy stapiają się ze sobą. W drobnych szczelinach między nimi ujawnia się wieloznaczność i niepewność odpowiedzi na pytanie o naturę kobiety.

Poznanie wiecznego przeznaczenia człowieka, kobiety i mężczyzny, umożliwia wiara. Wprowadzając perspektywę wiary, odwołuje się E. Stein do Pisma Świętego, czyli bezpośrednio do najbardziej podstawowych, źródłowych tekstów: do Księgi Genesis, do opowieści o stworzeniu człowieka mężczyzny i kobiety - i o grzechu pierworodnym. Także do listów św. Pawła i tylko w bardzo niewielkim stopniu do nauczania Kościoła w jej czasach.

Tekst Biblijny potrzebuje interpretacji - stwierdza E. Stein. Dokładniejsze omówienie tego, jak Edyta Stein czyta i komentuje Pismo, wymaga kompetencji teologa. Ciekawe byłoby porównanie jej odczytania kluczowych fragmentów dotyczących powołania kobiety ze współczesnymi interpretacjami.

Warto jednak zwrócić uwagę na kilka spraw. Opowieść biblijna przedstawia sytuację człowieka przed grzechem pierworodnym i po nim, naturę ludzką taką, jak została stworzona przez Boga, czyli w pewnym sensie doskonałą, pełną, oraz naturę, która uległa degeneracji.

Dwoistość tego, co być powinno - co jest wzorcem, ideałem, celem dążeń: prawdziwą istotą czy naturą wyznaczaną przez ponadczasowy porządek - oraz tego, co jest w świecie - niepełną, naznaczoną przez czas realizacją tego idealnego ładu - obecna jest zarówno w przestrzeni wiary, jak i w myśleniu filozoficznym właściwym tym kierunkom, z których wywodzi się filozofia Edyty Stein, czyli fenomenologii oraz myśli arystotelesowskiej i scholastycznej. Według nich, każdemu bytowi przysługuje istota czy forma, która stanowi o tym, czym on jest; doprowadzanie swojej formy czy istoty do pełni jest życiowym zadaniem i celem każdego bytu.

Powołanie człowieka według Ksiegi Genesis - mówi E. Stein - jest dla kobiety i mężczyzny jedno i wspólne: każdy ma być obrazem Boga, każde stworzenie ma na swój sposób być tym obrazem. Człowiek, kobieta i mężczyzna, jest powołany, żeby panować na ziemi i płodzić potomstwo. Przy czym (i tu pojawia się zróżnicowanie): każda płeć ma jedno z tych zadań jako prymarne, a drugie jako wtórne. Oboje stworzeni są jako wzajemnie sobie potrzebni i pomocni, stworzeni są do wspólpracy. Edyta Stein zdaje się 
sądzić, że pierwotnie, w porządku natury nieskażonej, integralnej, są sobie równi; podległość byłaby dopiero skutkiem grzechu pierworodnego. Choć raz wspomina o "chcianym przez Boga podporządkowaniu" (die gottgewollte Unterordnung)2, przeciwstawionym sytuacji podległości kobiet poddanych panowaniu, nieraz brutalnemu, mężczyzny.

Stein podkreśla, że każde stworzenie ma własną relację do Boga i nie potrzebuje pośrednictwa innych stworzeń. Także kobieta nie potrzebuje tu pośrednictwa mężczyzny. Stein wielokrotnie przywołuje wprowadzony przez Nowy Testatament ideał dziewictwa ${ }^{3}$, rozumiany jako brak uwikłania w więzi ze stworzeniem i pełne oddanie Bogu (co może stać sie powołaniem ludzi obojga płci i czego wzorami są i Maria, i Chrystus).

Edyta Stein wyraźnie mówi, że nie określa kobiety w relacji do mężczyzny; kobieta nie jest tylko nie-mężczyzną, chodzi o nią samą. Ideałem i celem wychowawania jest tu kobieta samodzielna, osoba dojrzała, pełna, harmonijna wewnętrznie, a nie jednostronna. Rozum, wola i uczuciowość (Gemuet) powinny współdziałać ze sobą we właściwym porządku. Człowiek, kobieta czy mężczyzna, świadomie siebie tworzy, a nie tylko biernie podlega wpływom, rozwija swoje zdolności, swoje siły - czyli realizuje swoje powołanie, zawsze indywidualne, swoiste. Nie znaczy to, oczywiście, że każdy robi to samodzielnie. Do ludzkiego, a przede wszystkim kobiecego powołania należy też współpraca i pomoc drugiemu w jego wypełnieniu.

Człowieczeństwo, tak samo kobiecość, jak męskość, zawsze realizuje się w konkretnej, indywidualnej jednostce: niepowtarzalnej, obdarzonej swoistością (Eigenart), określonymi zdolnościami, siłami, predyspozycjami, które powinna ona rozwijać i wykorzystywać. Wszystkie trzy poziomy czy kręgi składajace się na istotę konkretnego człowieka, to znaczy: (1) człowieczeństwo, (2) kobiecość lub męskość oraz (3) indywidualność, powinny zostać w jego życiu rozwinięte i dopełnione. Rozwój tego, co zostało dane przez naturę - lub też, mówiąc z perspektywy wiary, przez Boga - jest głównym zadaniem każdego człowieka, kobiety i mężczyzny. Edyta Stein wyraźnie i wielokrotnie przypomina, że jest to także pierwsze i najważniejsze zadanie kobiety - rozwój swoich zdolności, wykorzystanie swoich sił, doskonalenie siebie jako człowieka, kobiety i indwidualnej osoby. Nie ma mowy o niczym takim, jak przekreślanie siebie, swojej człowieczej, kobiecej i indywidualnej natury w imię jakichś innych celów czy zadań. Wielu kobietom nie wystarcza dom i rodzina jako przestrzeń realizacji swoich zdolności i możliwości. Niewystarczalność ta jest uzasadnieniem dla ruchów emancypacyjnych, domagających się szerszego pola działania dla kobiet.

\footnotetext{
2 Tamże, s. 141.

${ }^{3}$ Por. tamże, s. 24, 25, 40, 59, 135 i 149.
} 
Realizacja indywidualnych uzdolnień nie wchodzi w sprzeczność z kobiecością, Edyta Stein jest przekonana, że rozmaite, nawet tradycyjnie męskie zadania i zawody można wykonywać po kobiecemu. Powołanie ogólnoludzkie, kobiece i indywidualne jest jednością, a nie trzema powołaniami. To, jak owo powołanie dokładnie wygląda, zależy od natury konkretnej osoby. Pierwszeństwo tego, co indywidualne, jest tu niewątpliwe, i to właśnie należy przede wszyskim brać pod uwagę $\mathrm{w}$ procesie kształcenia.

Indywidulność wymyka się poznaniu naukowemu i filozoficznemu. Nauki empiryczne - anatomia, fizjologia, psychologia posługująca się metodami eksperymentalnymi lub rozumiejącymi oraz pokrewne dziedziny nauki - a także doświadczenie potoczne i codzienne mają ograniczoną zdolność uchwytywania tego, co istotowe. Nagromadziły one sporą i rozmaitą wiedzę o kobiecie, porządkują ten dorobek i uogólniają, wyróżniają typy kobiet, próbują powiedzeć coś o jej naturze, ale dotyczy to zawsze tego, co "przeciętne". Edyta Stein jest w pełni świadoma ograniczeń nauk empirycznych (nie mówiąc już o przednaukowym doświadczeniu), ponieważ ilekroć odwołuje się do obserwacji, czy to naukowych, czy potocznych, pojawia się słowo „przeciętne” (durchschnittlich). Przeciętna kobieta ma jakąś określoną naturę i zachowuje się $\mathrm{w}$ pewien sposób. Przeciętne kobiety dzielą się na pewne typy. Ale przypadki nieprzeciętne niezbyt się $\mathrm{w}$ takich podziałach mieszczą. Nie wiadomo też na tej podstawie zbyt wiele o tym, co konieczne, a co zawarte byłoby w samej istocie kobiety.

Gdyby różnica płci była tylko różnicą typów, możliwe byłoby przejście między jednym a drugim (co nie jest aż tak absurdalne, jak się wydaje - zauważa Edyta Stein - nie tylko różnice psychiczne są płynne, można przytoczyć fakty świadczące przeciw nieprzekraczalności różnicy budowy ciała4). Różnica płci to różnica species. Species, w przeciwieństwie do zmiennych typów o nieostrych granicach, to coś stałego, trwającego pomimo zmienności, wspólne jądro różnych typów 5 .

Pytanie o species "kobieta” jest dla Edyty Stein zasadniczym pytaniem spośród wszystkich pytań o kobietę ${ }^{6}$. Gatunek „człowiek” - czy raczej, jak lepiej w tym kontekście powiedzieć, species „człowiek” - jest podwójny, przejawia się na dwa sposoby - jako kobieta i mężczyzna, a w każdym z nich wyraża się bez ograniczeń istota człowieczeństwa7. Species jest tym - pisze

4 Por. tamże, s. 121.

${ }^{5}$ Por. tamże, s. 109 i 120.

6 „Die Frage nach der Spezies «Frau» die Prinzipienfrage aller Frauenfragen ist”. Tamże, s. 121.

7 „Die Spezies «Mensch» sich als Doppelspezies «Mann» und «Frau» entfaltet, dass das Wesen des Menschen, an dem kein Zug hier und dort fehlen kann, auf zweifache Weise zur Auspraegung kommt". Tamże, s. 138. 
E. Stein - co tomiści nazywają formą, wewnętrzną formą, która określa strukturę rzeczy ${ }^{8}$. W książce Byt skończony a byt wieczny (Endliches und Ewiges Sein), pojęcie species utożsamia się z ideą: mówi się tam o species albo idei czerwieni $^{9}$. Z kolei idea $\mathrm{w}$ sensie platońskim (eidos), a według Arystotelesa eidos (prawzór, Urbild) albo morfe (forma, Form) - to Wesenheit ${ }^{10}$. Określenie to można przełożyć jako „istotność”, ,"czysta jakość idealna” albo, jak w polskiej wersji Endliches und Ewiges Sein, jako "moment istotowy”.

Jeśli czerwień czy radość to Wesenheit, można też mówić (choć Edyta Stein tego nie robi) o Wesenheit kobiety, kobiecości. Wesenheit jest czymś prostym, niemożliwym do zdefiniowania, czymś, co może tylko zostać wskazane i doświadczone. Jest zastawane, a nie tworzone jak pojęcia ${ }^{11}$. Jako czysta forma czegoś, dana w doświadczeniu, ale wykraczająca poza nie, stanowi dla rzeczy ideał, doskonałość, granicę, miarę (Ideal, Vollkommenheit, Grenze, Massstab, Endliches) ${ }^{12}$. Wesenheit istnieje na sposób bytu istotowego (wesenhaftes Sein), natomiast istota (Wesen) jest istotą czegoś, jakiegoś bytu, należy do przedmiotu (gehoert zum Gegenstand) ${ }^{13}$. Można więc pytać o istotę (Wesen), o Wesenheit albo species kobiety.

Poznanie istoty, nieosiągalne dla nauk pozytywnych, możliwe jest dla filozofii. Fenomenologowie zakładają możliwość oglądu istoty (Wesensanschauung) - jest to akt intuicji, który wydobywa z konkretnego przedmiotu jego ogólną strukturę ${ }^{14}$. E. Stein porównuje tę metodę fenomenologicznego oglądu istoty do metody abstrakcji stosowanej przez tomistów. Używa jednak, pisząc o kobietach, pojęcia istoty (Wesen) bardzo rzadko, woli pojęcie natury. Te dwa pojęcia są sobie bardzo bliskie, niemal tożsame, można powiedzieć, że natura to istota, ale potraktowana z pewnego punktu widzenia, bardziej praktycznego. E. Stein, precyzując rozróżnienie istoty i natury, pisze, że oba pojęcia oznaczają to, czym (albo lepiej: „co") rzecz sama w sobie jest (das, was das Ding in sich selbst ist) ${ }^{15}$. "Co" (Was) może być jednak ujmowane z różnych stron. Gdy chodzi o to, czym rzecz właściwie i koniecznie jest (was es eigentlich und notwendig ist), $\mathrm{w}$ przeciwstawieniu do przypadkowych własności, zachowań, sposobów przejawiania się, lepiej pasuje określenie „istota” (Wesen). Określenie „natura” używane jest, gdy chodzi o to,

\footnotetext{
8 „Eine innere Form, die den Aufbau eines Dinges bestimmt”, Tamże, s. 120

${ }^{9}$ E. Stein, Byt skończony a byt wieczny, tłum. J.I. Adamska OCD, Poznań 1995, s. 302.

${ }^{10}$ Tamże, s. 97; E. Stein pisze tam o Wesenheit radości. Por. też: tamże, s. 107.

11 Por. tamże, s. 100.

12 Tamże, s. 266.

13 Tamże, s. 107.

14 "An konkreten Gegenstaenden ihre allgemeine Struktur zur Abhebung bringt”. E. Stein, Die Frau..., dz. cyt., s. 126.

15 Tamże, s. 130.
} 
co jest rzeczy udzielone $\mathrm{w}$ akcie stworzenia, jako co ona istnieje i przez co jest warunkowana do działania ${ }^{16}$.

Poznanie istoty osiąga się dzięki metodzie filozoficznej - twierdzi E. Stein - natura natomiast odsłania się w wyniku rozważań teologicznych. Może się okazać, że tak uzyskane istota i natura nie pokrywają się. To albo skutek błędu, albo może być tak, że istota i natura, zgodnie ze swym sensem, nie są ze sobą tożsame ${ }^{17}$. E. Stein pisze, że można pojęcie natury ująć tak, że dopuszcza ono przemiany bez utraty koniecznej istoty ${ }^{18}$. Możliwa jest indywidualna rozmaitość: „Nie każda kobieta jest czystym wcieleniem kobiecej istoty”"19.

Pojęcie natury wydaje się więc bardziej przydatne, gdy chce się uchwycić wieloraką i zmienną rzeczywistość bytów w rozwoju i działaniu, natomiast istoty rzeczy okazują się nie w pełni poznawalne. Istoty, zawarte jako prawzory w Boskim Logosie:

Okryte są welonem tajemnicy, zasłaniającym przed nami wszystko, co boskie, a jednak pozwalającym dojrzeć pewne jego kontury. Ten welon okrywa również wewnętrzne określenie istotowe rzeczy, które na pierwszy rzut oka przejawia się jako coś tak jasnego i tak prozaicznego, i które faktycznie przecież jest tym, co właściwie dla nas „pojmowalne”, czyli tym, co usiłujemy ująć za pomocą naszych pojęć20.

W dodatku istota nie da się na „pojedyncze rysy rozłożyć ani z nich złożyć. Jest ona czymś jednolitym i całym i czymś więcej niż sumą wszystkich poszczególnych rysów" 21 .

Podobnie, albo jeszcze bardziej, trudno poznawalne są istoty indywidualne, określające swoistość jednostkowych bytów. Swoistość (Eigenart) ta dana jest w akcie duchowego czucia (Fuehlen), czyli bezpośrednio w czymś w rodzaju intuicji, bliskiej uczuciu; czynne jest tu serce, uczuciowość (Gemuet). Swoistość nie jest poznawalna pojęciowo, nie da się jej rozłożyć na poszczególne składniki, także nie da się „rozłożyć na trochę wspólnego i trochę różnego" 22 - jak pisze E. Stein, odnosząc się do porównywania swoistości mojej i drugiego ${ }^{23}$. Znaczy to, że nie da się oddzielić w mojej indywidualnej istocie tego, co ogólne, od tego, co tylko moje.

\footnotetext{
16 „Das, was dem Ding durch den Schoepfungsakt mitgegeben ist, das, als was es ins Dasein gesetzt und womit es zu wirken bestimmt ist". Tamże.

17 „Dass Natur und Wesen sich ihrem Sinne nach nicht voellig decken”. Tamże.

18 Tamże.

19 "Nicht jede Frau ist eine reine Verkoerperung des weiblichen Wesens". Tamże, s. 69.

${ }^{20}$ E. Stein, Byt skończony..., dz. cyt., s. 269.

21 Tamże.

22 Tamże, s. 495.

${ }^{23}$ Tamże.
} 
Jeśli tak, to zawsze mamy do czynienia z tym, co niepowtarzalne i swoiste, własną realizacją species czy też Wesenheiten człowiek i kobieta/mężczyzna. Właściwą rzeczywistość stanowią konkretne jednostki ludzkie, realizujące człowieczeństwo i kobiecość (resp. męskość) zawsze na swój własny sposób, jednostki obdarzone swoją własną, indywidualną, niepowtarzalną istotą.

Osoba jest zawsze obdarzona płcią i nie jest to coś, co się tylko dołącza do pozostałych, ogólnoludzkich cech. Nie jest tak, że budowa ciała i jego funkcje stanowią o różnicy płci, a tam, gdzie przechodzimy na poziom ducha, różnica znika. Edyta Stein jest przekonania, że różnica płci, swoistość bycia kobietą (resp. mężczyzną) naznacza całego człowieka, ciało, psychikę, związek między ciałem i duszą, także ducha. Człowiek jest sobą w całej swej strukturze (Aufbau) jako kobieta lub mężczyzna.

Edyta Stein wymienia kilka cech, które uważa za szczególnie właściwe kobiecej naturze: nastawienie na konkret, całościowość podejścia do świata i ludzi (mężczyźni mieliby być skłonni do abstrakcji i jednostronności), nastawienie na osobę (mężczyźni są nastawieni bardziej rzeczowo [sachlich]), umiejętność wczuwania się $\mathrm{w}$ drugiego, troska o drugiego, to, co można nazwać macierzyńskością; wreszcie kobieta przede wszystkim pragnie kochać i być kochaną, chce pełnego oddania w miłości, zdolna jest do poświęceń.

Wymienianie konkretnych własności, które miałyby charakteryzować kobiety i odróżniać je od mężczyzn, łatwo daje się skrytykować - zawsze można pokazać, że wiele kobiet wcale tych cech nie posiada, za to jest wielu mężczyzn, którzy je mają. Znowu więc musi pojawić się słowo „przeciętnie". A co do własności i postaw, które są najgłębsze, najbardziej podstawowe, a przy tym najpiękniejsze, tak bardzo ludzkie i chrześcijańskie - czy można je przypisać jednej płci, a przez to jakoś odmówić ich tej drugiej? Edyta Stein powie, że kobiety i mężczyźni mają tę samą człowieczą strukturę (Aufbau), tylko proporcje są inne.

Ideał człowieka według Edyty Stein to ktoś nie tylko w pełni dojrzały, rozwijający swoje zdolności i siły, samodzielny, ale także rozwijający się harmonijnie, wewnętrznie integralny, u kogo rozum, wola i uczuciowość (Gemuet) pozostają we właściwych relacjach. Jest to ideał dla obu płci i jeżeli ktoś wykazuje tu nierównowagę czy brak, dobrze byłoby to zrównoważyć. Dlatego w wychowaniu dziewczynek dobrze jest kształcić nie tylko uczucia, ale też rozum i wolę i kierować je także w stronę rzeczowych (sachlich) zainteresowań. Rolę kobiety u boku mężczyzny widzi E. Stein także $\mathrm{w}$ ten sposób, że kobieta stara się uchronić mężczyznę przed jednostronnością, dba 
o jego harmonijny rozwój. Czyli byłby to ideał wzajemności, komplementarności, współpracy.

Obie płcie zbliżają się do siebie i jednoczą w najwyższym ideale człowieka, w człowieku świętym. Święte kobiety mają w sobie wiele cech męskich, święci mężczyźni stają się bardziej kobiecy24. Ideał komplementarności oraz ideał harmonijnego i pełnego człowieczeństwa dochodzi tu do szczytu. Pełny, doskonały człowiek łączy w sobie rozmaite ludzkie własności, męskie i żeńskie, w przecietnej populacji rozrzucone mniej harmonijnie, bardziej jednostronnie.

Czyżby więc na tym najwyższym poziomie człowieczeństwa znikała różnica płci, a przynajmniej zacierałaby się? Na pewno nie. Dla Edyty Stein bycie kobietą jest wartością nieodłącznie związaną z byciem sobą, $\mathrm{z}$ rozwojem indywidualności. Czy jednak kobiecość lub bycie kobietą daje się wyrazić jako zbiór własności czy nawet proporcji i relacji między własnościami? Czy nie pozostaje ciągle poczucie niewystarczalności i podważalności tego sposobu opisu? Może kobiecość (i podobnie męskość) jest prostą jakością, należącą do istoty człowieka tej konkretnej płci, jakością postaciową, nadającą swoiste zabarwienie wszystkim jej czy jego cechom, postawom, zachowaniom itp., jakiekolwiek by one były, ale do nich niesprowadzalną. Naznaczającą wyraźnie całą osobę. Bezpośrednio daną w doświadczeniu, w intuicyjnym czuciu (Fuehlen), ale w zasadzie niemożliwą do zdefiniowania, jedynie opisywaną w sposób dość okrężny i niewystarczający.

Propozycja taka nie została nigdy wypowiedziana przez Edytę Stein. Ale na pewno byłaby skłonna ją rozważyć, wywodzi się przecież z ducha jej własnej filozofii.

\section{Can One Speak of the Nature or Essence of a Woman?}

\section{Summary}

The issue of the nature or essence of a woman is a very practical problem for Edith Stein. The upbringing and education of women should be based on knowledge of a woman's nature and her life's vocation. Edith Stein makes use of science - particularly psychology - literature, common knowledge, and above all, philosophy and the Biblical message of faith. Women and men have a common basic vocation, to be an image of God, and both need to develop their talents, capabilities and powers in a full and harmonious manner. This development comprises three levels: humanity, femininity or masculinity and their singular individuality. Edith Stein's approach to the specific character of a woman's nature is holistic, concrete and personal, based on a maternal and caring attitude, and above

${ }^{24}$ E. Stein, Die Frau..., dz. cyt., s. 44. 
all on the desire to love and be loved. Edith Stein describes nature or essence from the perspective of action. Like the essence of things, the individual specificity of each person is not fully knowable; it can be known only intuitively. One might formulate the hypothesis that femininity is a simple and irreducible quality that affects the whole structure of a person. 